\title{
The Argument for Choosing State's Judicial System or a "Private" Outsourced Resolution of Disputes: a Practising Attorney's Point of View
}

\begin{abstract}
JORG SLADIČ
Abstract Terms such as arbitration, mediation, conciliation and alternative dispute resolution (ADR) are nowadays standard terms in any classroom textbook on civil procedure. Legal scholars enumerated and assessed in depth the advantages and disadvantages of any type of outsourced dispute resolution. However, a number of legal writers still fail to enumerate the exact differences in course of events and all of the trade-offs that a party will have when deciding to resolve the dispute using an outsourced dispute resolution. Clearly the costs, the celerity and the flexibility are important issues. However, the decision is not influenced solely by legal arguments. This paper will mention some typical Slovenian issues in an assessment of the choice of dispute resolution. If parties want to continue to remain in good terms after the dispute, then an outsourced dispute resolution is highly recommended. Judicial rulings are to binary; one party wins, one loses.
\end{abstract}

Keywords: • ADR $\bullet$ arbitration $\bullet$ mediation $\bullet$ outsourced mediation $\bullet$ courtconnected mediation $\bullet$ choice of ADR • State as party in litigation and ADR•

CORRESPONDEnCE AdDRESS: Jorg Sladič, Ph.D., Assistant Professor, Law office Sladič-Zemljak, Kersnikova 7, 1000 Ljubljana, Slovenia, University of Maribor, Faculty of Law, Mladinska ulica 9, 2000 Maribor, Slovenia, e-mail: jorg.sladic@gmail.com. 


\section{$1 \quad$ Introduction}

Much has been written on the advantages of private outsourced resolution comprising of several forms of court-annexed, court-connected and out-of-court mechanisms of dispute resolution. However, modern legal writers seem to still be divided over the issue of the legal definition and status of various "outsourced" dispute resolution methods. Do negotiations (that might be unsuccessful and be followed by litigation or arbitration) already fall under the scope of "outsourced" dispute resolution (Đuričin, 2013: 606). Perhaps common law lawyers familiar with multi-tiered dispute resolution clauses and multi-step resolution clauses will concern negotiations already as an outsourced dispute resolution (Đuričin, 2013: 606). However, in Slovenia they are not considered as a genuine dispute resolution. Rather negotiations after a failed performance of a contract are considered as part of an attempt to achieve a specific performance that is deemed to be the natural remedy in law of obligations (under the pacta sunt servanda rule of Slovenian private law) and are not considered as a dispute resolution mechanism. ${ }^{1}$ Negotiations are rather considered as a very effective method of the prevention of disputes. The general approach in Slovenia is: we shall negotiate before we have a dispute.

The Recommendation No. R (86) 12 of the Committee of Ministers to Member States concerning measures to prevent and reduce the excessive workload in the courts of 16 September 1986 shall also be mentioned. ${ }^{2}$ A friendly settlement of disputes, either outside the judicial system, or before or during judicial proceedings shall be encouraged. One of the solutions proposed by that Recommendation of soft law is also "entrusting the judge, as one of his principal tasks, with responsibility for seeking a friendly settlement of the dispute in all appropriate matters at the commencement or at any appropriate stage of legal proceedings". This has led to a very interesting development of court settlements (sodna poravnava) under Slovenian civil procedure.

As far as civil procedure and outsourced resolution of disputes in Slovenia are concerned the most known and important terms are arbitration and ADR. Slovenian scholars seem to include arbitration in the scope of ADR and give the following definition: ADR is any form of consensual dispute resolution without an intervention of State's courts (Betetto and Galič, 2009: 17). The Slovenian definition seems to be somehow influenced by Slovenian legislation. Indeed Art. 2 of the Slovenian Act on Alternative Resolution of Judicial Disputes ${ }^{3}$ defines the ADR as proceedings that are not litigation and in which one or several neutral persons cooperate in resolution of a dispute $[\ldots]$ by applying mediation, arbitration, early neutral assessment or other similar proceedings. However, arbitration is in some ways far too similar to litigation to be considered as a genuine ADR. This is clearly acknowledged by jurisprudence. Indeed, "a resolution of a dispute before an arbitration does not represent a method for an amicable resolution of a dispute (like e.g. mediation) [...]. It is a substitute form of judicial protection, as an arbitration decision produces equivalent effects as a final judicial decision (res iudicata)" ${ }^{4}$ ADR shall be defined as any form of dispute resolution facilitated by a neutral third party that is not a trial or litigation before a State appointed judge or judicial panel (conciliation, mediation, 


\section{LEXONOMICA \\ J. Sladič: The Argument for Choosing State's Judicial System or a "Private" Outsourced Resolution of Disputes: a Practising Attorney's Point of View}

arbitration, mediation/arbitration, arbitration/mediation, etc.) (Jovin-Hrastnik, 2009: 1123-1124).

Genuine ADR and arbitration are nevertheless both a form of an outsourced resolution of disputes. A dispute resolution that is not performed by the State's courts seems to be an ancient institution which was already in use by the ancient Babylonians, Chinese, Phoenicians, Greeks and Romans (Spillane, 2011: 142; Miranda, 2014: 9-11). Standard wisdom has it that ADR and similar outsourced methods of dispute resolution, such as arbitration, are slowly and progressively replacing the State's judicial system due to a rather beneficial, benevolent and speedy nature of dispute resolution as compared to a coercive and slow nature of State's court (Spillane, 2011: 142; Langbein, 2012: 119-149). Europeans seem to be reluctant and are trying to set up a defence of a judicial system (Stürner, 2014: 632). American legal writers speak very drastically of a change from the courtroom to the conference table (Calkins, 2011: 15). However, the best critique of ADR is found when medical science is compared to law. Do patients want alternative medicine or normal, modern medicine. Applied to law this means that parties do not necessarily want an ADR solution to their dispute, as ADR has the same consideration regarding judicial proceedings as alternative medicine has to medicine practised in hospitals.

If we leave the legal theory and go to everyday practice, we might find that there is more to it when choosing a dispute resolution mechanism. When choosing a path to solve a dispute, an attorney must take into consideration that the content of any dispute is linked to human relations. The law is only a tool to solve such a dispute in a civilized manner i.e. in a socially acceptable manner. The big failure of a judicial or State conducted resolution of disputes is the compelling binary logic, namely that one party of the dispute is always the loser. On the other hand, outsourced dispute resolution allows a win-win situation that is in judicial resolution of disputes only possible in case of court settlements. This might imply a different treatment of ordinary civil disputes (including the family law linked disputes, issues linked to property law and tenancy like e.g. actiones possessoriae, easements) and commercial disputes (i.e. disputes between legal persons of commercial law) as compared to disputes with the State. The tendency in Slovenia is that disputes or at least the part of disputes that falls in competence of civil courts in ordinary or commercial procedure - with State agencies and State owned enterprises do not follow the logic that compels legal subjects of private law to outsource their disputes.

A practical approach is that a negotiated solution is better in cases where there will continue to be (continuous) contractual or other links (like in custody cases). However in Slovenian practice issues like confidentiality are not that important. Fees and costs have a significant importance, especially in labour cases, as mediations are free of charge in labour matters (Škundrić, 2012: 2). It must be said that outsourced dispute resolution like conciliation and arbitration have a long tradition, especially in labour matters. ${ }^{5}$ Nevertheless, the initial costs of litigation in first instance, arbitration and event court annexed mediations in civil, commercial and labour cases are virtually identical due to identical bar tariffs and stamp fees. The monetary consideration is seen only after the friendly conclusion of a litigation in form of restitution of stamp duties. The most 
important issues are rather the speed and the quality of the proposed resolution of disputes. In Slovenia, as far as the quality is concerned - surprisingly enough - an argument can be heard that a mediation or an arbitration might indeed be faster than judicial proceedings. However, judicial proceedings allow the access to appellate courts and sometimes to the Supreme Court. Appellate judges are deemed to be of high quality, and therefore a judicial resolution of a dispute might, due to the quality of the ruling, be of higher interest for the parties than a fast arbitral award that is not rendered by appellate judges. The reason is that managers of Slovenian state owned enterprises seem to operate solely by legal opinions rendered by their legal services and are often afraid to opt for an ADR rather than long judicial proceedings due to their liability to shareholders. In other words, if an independent court rules against such a company, a company's director will not be liable. An independent court ruled according to the law. If, on the other hand, the company's director will opt for a fast and negotiated resolution of a dispute ending in a pecuniary lower award than a court would render, the shareholders might hold him liable as he did not go before the courts and fight the case until the end.

This paper shall examine the issues an attorney or an in-house lawyer has to assess when choosing the path to the resolution of a dispute. It is contended that the most important characteristics of a State's court system and comparing them to outsourced private dispute solution shall be used as the first criterion (2.). The next chapter will deal with the issue of court settlements as a mixed creature between outsourced and State sponsored dispute resolution (3.). One common error in Slovenia is to consider outsourced dispute resolution as a trial by private judges (4.), as such a resolution might also allow for a decision ex aequo et bono (5.). Some forms of outsourced dispute resolution are linked to the "arbitrability" (6.). If one party to a dispute unconditionally wants a ruling by a State's court, no form of outsourced dispute resolution will convince that party to resort to outsourced dispute solution. That party will even consider any outsourced dispute resolution as infringing his/her right to an effective judicial remedy. In the continuation the place taken by the term restorative justice - referred to especially in common law jurisdictions - in Slovenian civil procedure shall briefly be examined (7.). The next chapter will refer to issues linked to Art. 6 of the European Charter of Human Rights ((ECHR) fundamental right to access to courts in civil matters) and outsourced dispute resolution (9). The main issues are the celerity of a resolution and confidentiality (10. and 11.). The last chapter will deal with an interesting Slovenian anomaly in disputes with State owned enterprises, namely a de facto refusal of any outsourced settlement of disputes due to issues linked to political and extra-contractual liability of administrators and CEOs of such entities.

The imperium of State's courts: the main difference between outsourced and in-house dispute resolution in modern civil procedure?

In Slovenia a rather long duration of judicial proceedings in private law combined with (we could almost be compelled to say traditionally) ${ }^{6}$ low appreciation and a generalised distrust of the judicial system and judicial personnel is slowly causing the creation of additions and alternatives to the traditional framework of judicial resolution of disputes. 


\section{LEXONOMICA \\ J. Sladič: The Argument for Choosing State's Judicial System or a "Private" \\ Outsourced Resolution of Disputes: a Practising Attorney's Point of View}

One might perhaps add that the loss of confidence "in the capacity of judges and other traditional authorities" seems to be a common denominator in modern Europe (de Roo and Jagtenberg, 2012: 27). Slovenia does not seem to be an exception as far as the issue of distrust is concerned (Uzelac, Aras, Maršić, Mitrović, Kauzlarić and Stojčević, 2010: 1266-1267). The Slovenian specificity linked to a general mistrust in the judiciary is linked to the issues of the transition from a socialist judiciary to a modern, more liberalminded European judiciary. Such a transition is perceived by the public as failed or even as utterly failed (Uzelac, 2010: 387).

Recent reforms in Slovenia have emphasised the importance of negotiated resolutions of disputes also in the framework of judicial proceedings, be it in civil or even criminal cases. If a negotiated resolution can be achieved either in State's judicial system or in an outsourced dispute resolution system, one must examine the rationale to litigate before courts or to undergo an outsourced dispute resolution. Nowadays participating parties in the majority of disputes can resort to trial before a State's courts, arbitration or some other form of mandatory or voluntary mediation. Formalities required for commencing any type of dispute resolution (litigation, mediation and arbitration) are very similar. Writs or applications commencing the proceedings are extremely similar in litigation and arbitration. Even though mediation does not form a part of judicial proceedings in civil matters, ${ }^{7}$ in court-annexed or court-connected mediations written submissions that are lodged with the court are identical as in judicial proceedings. Indeed, in Slovenia an arbitration shall be commenced by the writ informing the other party of the arbitration. ${ }^{8}$ In reality this writ seems to be quite an informal notice conferring the intent to arbitrate to the other defendant.

Similar conclusions can be reached when examining the Slovenian Act on Mediation in Civil and Commercial Matters. ${ }^{9}$ Art. 6(1) of the said Act states that if parties reached an agreement to resolve mutual disputes that can arise of a certain legal relation or if mediation is fixed by law for certain kind of disputes, a mediation shall be commenced when the other parties received the notice of mediation.

Under Art. 25 of the Slovenian Act on Arbitration, unless agreed otherwise by the parties, the application (tožba) and the defence (odgovor na tožbo) must be lodged by the deadline fixed via the arbitration panel. Both written submissions must contain at least a definite claim (form of order sought in Europe or prayer for relief in other parts of the world), the facts on which the claim is based and contentious questions among the parties. Written evidence might be annexed. Parties might also refer to the evidence that will be adduced during the course of proceedings. Under general rules of civil procedure (Art. 179 and 180 of the Slovenian Code of Civil Procedure ${ }^{10}$ ) an application (tožba) commencing the proceedings "the application shall comprise a definite claim" (form of order sought in Europe or prayer for relief in other parts of the world) as to the principal and accessories of cause are concerned, facts on which the claimant bases his/her claim, evidence by which the facts shall be established and other data that any written submission must contain (i.e. the name of the court, the domicile or the temporary residence of the registered office of the parties, their eventual representatives and agents, the subject- 
matter of the dispute and the narration of the party). In other words, as far as the difference in formal preparation of the dispute settlement, there is virtually no difference between judicial and outsourced resolution of disputes.

\section{Transition without boundaries between the judicial and outsourced resolution of disputes: court settlement and the Slovenian type of mediation}

Since creation of a modern court's system after the end of feudal era in Slovenia (after the abolition of patrimonial justice in 1848 in Imperial Austria) relief sought by individuals was obtained in civil and commercial cases before the State's court. That type of judicial proceeding has traditionally been represented by a linear interaction between the claimant, the defendant and the trial court closed by a final decision (and enforceable decision at least in the case where a compelling decision was sought by the parties) settling the dispute by applying the law (processus est actus trium personarum-actoris, rei et iudicis). The claimant is seizing the court in order to get the relief sought in his/her application. The form of relief on the merits sought is defined exclusively by the claimant (ne procedat iudex ef officio, the claimant is the dominus litis). Slovenian law applies the principe dispositif. The court shall not adjudicate extra et ultra petitum. The defendant also has the right to lodge a defence, as the court of law is under obligation to issue a ruling on the merits of the case. Decisions adopted by State's courts are acta iure imperii. In other words, the court is empowered to impose its own solution of a dispute to parties (the claimant and the defendant). The solution of a dispute before the court can only be binary: a party either loses or wins the case. As far as legal practitioners are concerned, in case of a favourable decision, the case was won by both: the party and the attorney. If the case is lost, then the party lost the case.

Traditionally in Slovenia trial courts, in matters of private law, lato sensu (ordinary courts in civil and commercial cases and labour courts in labour disputes) can grant relief that can be either a declaration on the existence or non-existence of a right, legal relation or authenticity of a document (actio declaratoria) ${ }^{11}$ either a creation, termination or modification of a right, obligation or legal relation (actio constitutiva $)^{12}$ or a compelling judgement ordering the defendant to perform an obligation dandi, faciendi, praestandi or ommittendi (actio condemnatoria). ${ }^{13}$ In other words: if an applicant wants to get a declaration by a trial court (like in cases of declaration of paternity or of adverse possession (usucapio), the relief granted by the court - of course if certain conditions of substantive law are met - will be a declaration of paternity or in cases of adverse possession a declaration of property. If the claimant wants a creation, termination or modification of a right, obligation or legal relation, such as in cases of a divorce or termination of a tenancy contract, then the relief granted will be a termination of marriage by divorce or a termination of a contract. An outsourced dispute solution that goes beyond negotiations and coordination, i.e. ending with a judicial compelling ruling is alas not allowed in Slovenian legal order, which will be explained below. Does this finding mean that certain disputes should be handled exclusively by the judiciary?

The answer is somehow sobering. A certain amount of judicial interference will always represent the characteristics of actiones declaratoriae and actiones constitutivae. 


\section{LEXONOMICA \\ J. Sladič: The Argument for Choosing State's Judicial System or a "Private" Outsourced Resolution of Disputes: a Practising Attorney's Point of View}

However, recent reforms of civil procedure in several countries in Europe (also in Slovenia) instituted or even reinforced the existing judge's possibility or even task to facilitate a negotiated settlement of a case instead of issuing a ruling on the merits. ${ }^{14}$ Some legal systems traditionally adhere to the active role of the judge in conducting of civil litigation (the old materielle Prozessleitung and the modern case management system, we even can speak of open methods of adjudication) that can facilitate a negotiated compromise within a concrete trial. In other words, judges also start to act as mediators/arbitrators within the framework of a concrete litigation instead of solely adjudicating the case by virtue of law based on facts submitted by parties (iura novit curia and da mihi facta, dabo tibi ius) and leaving everything else to the parties (Eiseman, Bulman and Dunn, 2013: 683-725). As far as mediation is concerned, it must be said that lawyers from civil law jurisdictions - especially from Member States knowing the active role of the judge in the settlement of cases - consider alternative dispute resolution (like mediation, etc.) rather as a fashion phenomenon originating in the US (Braun, 2014: 168). There are some critics, who to some extent have a negative attitude, write about conservatism of European legal orders (Knežević, 2012: 419). It is contended that outsourced and private solution of disputes like mediation were considered to be superior than well-established litigation and dispute solution techniques until the sobering effect of negative experiences with such newer mechanisms (Braun, 2014: 168). Some European legal scholars report that mediation and outsourced method of dispute resolution are considered by legal practice to be rather linked to family law than to commercial and business law (Schütz, 2015: 107).

On 27 February 2017 the Slovenian legislature adopted an important reform of Code of Civil Procedure. It would appear that the provisions on the preparatory hearing and judicial settlements were repealed due to an unknown reason. The problem is that the preparatory hearing worked well in practice, so the legislators "fixed" something that did not need fixing. Before the reform of the Code of Civil procedure in 2017 the introductory phase of a trial was at least becoming more and more similar to negotiations and mediations. Traditionally (nowadays under Art. 306 of the reformed Slovenian Code of Civil Procedure) parties can conclude a court settlement on the subject matter of the dispute before the trial court anytime during the proceedings. The court settlement can comprise whole of the claim, a part of it and even any other issue between the parties. If a court settlement is concluded, then the continuation of litigation is needless and there is no need for the operative part of a judgement (Sajovic, 1939: 330). However, the most important provision of the Slovenian regulation on court settlement is actually Art. 306(3) of the Slovenian Code of Civil Procedure. According to that provision "the court shall at any time in the proceedings have due regard to the conclusion of a court settlement, it shall draw attention of the parties to such a possibility and shall assist them in order to achieve a settlement". Although the current Slovenian Act on civil procedure was adopted in 1999, this provision constitutes ancient law going back to $\S \S 282-284$ of Code of Civil Procedure of the Kingdom of Yugoslavia and $\S \S 204-206$ of the Austrian Code of Civil Procedure. 
After the lodging of an application before the court of first instance and even after filing an appeal, the court of first instance or the court of appeal (as the case might be) will invite the parties to mediate the case on the basis of a voluntary court-annexed mediation. If the offer of mediation is refused the court of appeal will adjudicate the case on the merits. However, the more interesting repealed approach had been introduced by Art. 305.a-305.c of the Slovenian Code of Civil Procedure before the repeal in 2017. The following is more a historical overview. After the lodging of the defence the court ordered a settlement hearing that was not held in open court. According to the nowadays repealed Art. 305a(2) of the Slovenian Code of Civil Procedure, "During the settlement hearing the court must openly discuss factual and legal questions of the dispute with the parties in order to specify the essential contentious questions and assess the possibility of a court settlement and endeavour the conclusion of such a settlement." Only after a failed attempt to conclude a court settlement a trial could be ordered. ${ }^{15}$ The law did not stipulate a mandatory setting of a joint settlement hearing and the first trial hearing. ${ }^{16}$ However, if there was no settlement and the court considered that such a settlement could be concluded, it could adjourn the hearing. ${ }^{17}$ This possibility has been extensively interpreted by the case law. "In case, where the only remained open contentious issue was the difference in the salaries paid, the court of first instance could have and should have endeavour the conclusion of a partial court settlement by the parties that could have comprised the principal elements of the dispute, as Art. 305a of the Slovenian Code of Civil Procedure does not exclude a possibility of conclusion of a partial court settlement." 18

Nevertheless, the main characteristics of the State's courts is their iurisdictio and their imperium. A compelling decision handed down by State's courts is an enforcement title. In other words, a court condemning a party to an obligation dandi, faciendi, praestandi or ommittendi (actio condemnatoria) is acting as a branch of the State's authorities. In Slovenia this cannot be said of any outsourced dispute resolution. Purely outsourced resolution of disputes that are not an arbitration will not produce an enforcement title or any other form of compelling orders. If parties consent to a court-connected mediation and resolve their dispute, the agreement achieved in the mediation will be sanctioned by the trial court by accepting that agreement as a court settlement of a case (res transacta). Court settlements under Slovenian law have exactly the same effect as a judgement (res iudicata). Court settlements are enforceable. In Slovenian law the court settlement is a contract concluded by the parties in civil litigation (therefore, it also possesses the characteristics of a judicial decision).${ }^{19}$ According to case law a court settlement has the effects of a final judgement (res iudicata). ${ }^{20}$

The Supreme Court of Slovenia gave a statement of reasons under which, according to the majority of legal scholars in Slovenia, court settlements produce effects of substantive as well as of procedural law. Substantive effects can be seen in a settlement by mutual agreement of contentious legal relations under the rules of civil law (nowadays Art. 1050 Code of Obligations and before that $\S 1380$ of the ABGB), but on the other hand procedural law can be seen in the effects that are similar to final decisions (res iudicata). According to the Slovenian Supreme Court a concluded court settlement also produces 


\section{J. Sladič: The Argument for Choosing State's Judicial System or a "Private" Outsourced Resolution of Disputes: a Practising Attorney's Point of View}

procedural effects. However, procedural effects do not annul substantive effects, i.e. a contractual nature. ${ }^{21}$ The consequences being that they cause the ne bis in idem forclusion (they acquire the so called subjective res iudciata effect). A dispute settled by a court settlement cannot be object of a second judicial proceedings. In jurisprudence such a question was linked to the capacity to start a second actio finium regundorum. A boundary regulated by a final court settlement cannot be modified in new judicial or administrative proceedings. ${ }^{22}$ A court settlement concerning the subject matter of a civil action that had been concluded before the action was lodged produces effect of inadmissibility of that action. ${ }^{23}$

The wish to get an enforceable judicial decision or the possibility to settle a dispute without such a decision is the first criterion to be assessed when choosing the ways of resolution of a dispute.

\section{The judicial function: outsourced dispute resolution is not a trial by private judges}

The first error to avoid in the choice between a State's court and an outsourced dispute resolution is to consider the outsourced dispute resolution as a litigation before a nonState's judge, or rather a potentially non-partisan judge. Outsourced dispute resolution allows more than even a very liberal and not formalistic system of civil procedure known in Slovenia. However, it does not allow for a compelling judgement. In fine State's justice closing a case by a compelling judgement is always bound by the maxims da mihi facta, dabo tibi ius and iura novit curia. State's courts and even private and public arbitration courts and panels impose their resolution of a dispute even in cases when both parties (the claimant and the defendant) do not agree with the imposed solution. In Slovenian jurisprudence cases, where a court has dismissed a claim and counterclaim, are occasionally reported.

Nevertheless, courts have the coercive power to impose compelling judgements, while an outsourced solution of disputes is rather characterized by a manifest lack of such power. The current Slovenian Law on Arbitration requires even a national arbitration decision to be submitted to proceedings for obtaining enforceability (some sort of an arbitration exequatur) before the State's court. ${ }^{24}$ 
However, despite the generalised dissatisfaction with the judiciary lawyers having received legal training in civil law jurisdictions like Slovenia, they still look with distrust to outsourced dispute settlement mechanisms. This is rather surprising, as in certain fields of law (such as in sale's contracts) mechanism of dispute coordination and solution (nowadays re-codified in Art. 445 Code of Obligations) have been known since at least the $19^{\text {th }}$ century. Indeed, in Slovenia Art. 445 Code of Obligations stipulates:

"If the stipulation of the purchase money was entrusted to a third person that cannot or does not wish to stipulate the purchase money, and the contracting parties do not subsequently reach agreement thereon but do not annul the contract, appropriate purchase money shall be deemed to have been agreed." 25

In other words, the sale's price can be entrusted to a third "outsourced" independent person who is nevertheless under obligation to act upon joint instructions by the buyer and the seller. This is at least an outsourced coordination of opposing interests that might lead to a dispute.

A solution ex aequo et bono

An outsourced dispute resolution might also allow the achievement of a regular solution ex aequo et bono, which seems to be a rare case in ordinary judicial proceedings. It is said that the outsourced dispute solution is needs-based and not results driven (Calkins, 2011: 14). On the other hand judicial proceedings are in practice always results driven. The result is the form of relief sought by the party in the written submission, i.e. a condemnation to pay a sum of money, a divorce or a recognition of paternity.

In other words, in outsourced private resolution of disputes, parties can negotiate, mediate and even arbitrate. However, in almost any form of ADR (with the exception of arbitration) they can refuse a solution they do not like. A negotiated solution may better serve the parties' interests (like in cases of custody of minor children, contracts with long duration of performance like employment contracts, insurance contracts) as a very binary judicial ruling on the merits of a case.

A solution ex aequo et bono is nowadays offered by private outsourced resolution and also by State's resolution of disputes, be it in form of (mandatory) mediation or of court settlements of cases (res transacta). Parties that are ready to compromise might conclude a res transacta before the trial court or an agreement before the person conducting the outsourced dispute resolution. Arbitration, mediation and other forms of ADR can, due to their mixed nature, address issues that need no legal solution. In some ways after the reforms of civil procedure the ADR is losing its main advantage i.e. a negotiated flexible solution of a case more or less satisfying both the claimant and the defendant compared to a very binary judicial ruling on the merits (a claimant either loses or wins a case). At least in Slovenia compromises concluded before a trial court (res transacta) allow for the same level of flexibility as in mediation. Indeed, court-annexed mediation and court settlements are concluded under the same set of rules. 


\section{LEXONOMICA \\ J. Sladič: The Argument for Choosing State's Judicial System or a "Private" Outsourced Resolution of Disputes: a Practising Attorney's Point of View}

\section{What is the "arbitrability" stricto sensu as a criterion for outsourcing the resolution of disputes?}

As far as outsourced solution of disputes are concerned, Slovenian legal system does not allow for an outsourced resolution of disputes closed by a final (res iudicata) and enforceable decision in cases of certain actions for declaration and in cases of certain actions for creation, termination or modification of a right, obligation or legal relation. According to Art. 4(1) of the Slovenian Act on Arbitration, "any patrimonial claim may be an object of an arbitration agreement. Other claims can be arbitrated solely if parties can conclude a court settlement." This is a rather legalese way of saying that an arbitration is allowed only where the parties can freely operate with their rights and claims. A case where there is no such possibility would be a waiver of maintenance obligation by the mother for a minor child in divorce proceedings. Arbitrability is also an issue in mediations. Indeed, Art. 2(1) of the Slovenian Act on Medication in Civil and Commercial Matters provides that a mediation in civil, commercial, labour, family and other patrimonial disputes is allowed only where the parties can freely operate with their rights and claims and can conclude a settlement. In other words, Slovenian legislation has extended the term of arbitrability from arbitration to mediation regardless if the said mediation is based on an agreement concluded among the parties, compulsory law, referral to mediate or even suggestion to mediate by the court, arbitration or the competent body. ${ }^{26}$

A certain amount of judicial interference will always represent the characteristics of actiones declaratoriae and actiones constitutivae. Both types of actions are either covered by exclusive competence of State's courts or the parties have no power of free and unlimited operations with such rights. ${ }^{27}$ Of course parties can negotiate or even mediate in an outsourced mediation. However, the result will not always have legal effects of a final resolution of the dispute. The said cases allow only for a court-annexed or courtconnected mediations. The typical cases of such actions refer to personal status and family law (divorces, custodies, recognition of paternity, alimony, etc.), ownership and rights in rem on immoveable property. However, patrimonial property regimes between spouses can be arbitrated, spouses can freely operate with their rights under the matrimonial property regime. Such rights can also be subjected to a rather formalised outsourced dispute resolution, as any enforceable agreement on property regime between spouses (husband and wife) needs a form of a notarial act. ${ }^{28}$

The issue of arbitrability can be explained with two cases:

A lawsuit referring to a presumed invalidity/void of a patent cannot be arbitrated. On the other hand, damages caused by patent infringements can be arbitrated. A solution of disputed referring to actions for creation, termination or modification of a right, obligation or legal relation can be outsourced only under certain conditions (e.g. termination of employment contracts). A lawsuit concerning a divorce cannot be outsourced from courts. Nevertheless, a form of non-judicial dispute resolution, known as proposed mediation after the lodging of an 
application, is known in any judicial proceedings be it civil, commercial or labour.

A typical case for an outsourced dispute resolution would be a neighbourhood dispute concerning the rights of passage or easements between two neighbours. Slovenian law does not allow for genuine outsourced dispute resolution of issues linked to creation or extinction of easements as a ius in rem can only be created either by an agreement and tradition by the parties, a decision by a State's authority or ex lege. A genuine outsourced resolution of a dispute in such a case can therefore only be a contractual creation, modification or termination of rights in rem.

However, even patent validity and property rights disputes can be solved by an outsourced non-State resolution of a dispute in case of negotiations. Therefore, it would be wrong to consider that the term "arbitrability" of a dispute could be used as the main criterion for choosing a form outsourced dispute resolution (Sikirić, 2013: 493-519).

\section{$7 \quad$ The enforceable title v. resolution of a dispute?}

An enforceable title (titulus executions) is defined in Slovenia as a public document, by which the substantive claim for performance of an obligation dandi, faciendi, ommittendi and patendi is declared as enforceable (Juhart, 1962: 25 and 26). Unsurprisingly the outsourced dispute resolution can, as a rule, not lead to an enforceable title. However, a negotiated settlement might supersede a need for an enforceable decision.

Nevertheless, three exceptions shall be mentioned. The most common case is linked to disputes in family law. If a dispute between spouses ends in the splitting of matrimonial property concluded in a friendly manner, such a splitting shall be done in a form of a notarial deed that can also achieve the status of an enforceable title. A court settlement concluded after a court annexed mediation is also an enforceable title. An arbitral award, on the other hand, must be the subject matter of proceedings for obtaining enforceability (some sort of an arbitration exequatur) before the State's court.

Some applicants before civil courts do require an enforceable title. The Slovenian legislation allows a very short transition from court-annexed mediation to an enforceable title. Indeed, under the Slovenian Act on Mediation in Civil and Commercial Matters ${ }^{29}$ a successful court-annexed mediation is then formalised in a form of a court settlement. A successful outsourced mediation can be, according to the Act on Mediation in Civil and Commercial Matters, formalised in a form of a notarial deed.

Therefore, in Slovenia the need to get an enforceable title cannot be considered as a criterion for choosing outsourced resolution of disputes. 


\section{LEXONOMICA \\ J. Sladič: The Argument for Choosing State's Judicial System or a "Private" Outsourced Resolution of Disputes: a Practising Attorney's Point of View}

\section{Restorative justice is not a cause for private and outsourced resolution of disputes}

The term restorative justice in civil procedure is virtually unknown in the Slovenian legal community due to several factors, but there are two that stick out the most. The first is linked to the very nature of powers vested with trial courts in civil matters (also in commercial and labour matters).

The reason linked to civil procedure is that in Slovenia trial courts can grant relief that can be either a declaration on the existence or non-existence of a right, legal relation or authenticity of a document (actio declaratoria), either a creation, termination or modification of a right, obligation or legal relation (actio constitutiva) or a compelling judgement ordering the defendant to perform an obligation dandi, faciendi, praestandi or ommittendi (actio condemnatoria). In other words, the courts' inherent powers in civil matters comprise also of reparation of a harm suffered by a victim and also by apologizing or the restitution of the harm done and not only in adjudication that ends with a compelling order to pay a certain sum of money. The form of relief sought by claimants depends solely on their initiative under le principe dispositif (Dispositionsgrundsatz).

The second reason is that as far as reparation of harm is sought, Slovenian substantive law adheres to the following scheme: restitution, reparation by monetary consideration and finally satisfaction (in cases of moral prejudice). Restitution is the form of restorative justice par excellence.

\section{Possibility of a negotiated resolution and the fundamental right to access of the courts}

This issue has been sometimes considered by legal writers when assessing the compatibility of arbitration with Art. 6 of the ECHR (Jung, 2014: 175-179). However, it is widely recognised that

"54. [...] Article 6 [ECHR] does not preclude the setting up of arbitration tribunals in order to settle disputes between private entities. Indeed, the word "tribunal" in Article $6 \S 1$ is not necessarily to be understood as signifying a court of law of the classic kind, integrated within the standard judicial machinery of the country. [... ]"30

One might conclude that this case concerned an arbitration in a post-soviet country. Nevertheless, the contents are clear. There is no obligation for the State to prevent an outsourced dispute resolution. In the continuation two questions can be raised. The first one might refer to the applicability of case law developed for arbitrations in other fields of outsourced dispute resolution. The European Court of Human Rights concluded in case Đorđević v Croatia that even a compulsory attempt of friendly settlement before lodging of a civil action does not infringe Art. 6(1) ECHR (in case of action for extra-contractual liability against the State). 
The second question is linked to compulsory mediation, i.e. can an attempt to mediate constitute a condition of admissibility of a civil action. The Court of Justice of the European Union considers that

"Article 34 of Directive 2002/22/EC of the European Parliament and of the
Council of 7 March 2002 on Universal Service and users' rights relating to
electronic communications networks and services (Universal Service Directive)
must be interpreted as not precluding legislation of a Member State under which
the admissibility before the courts of actions relating to electronic
communications services between end-users and providers of those services,
concerning the rights conferred by that directive, is conditional upon an attempt
to settle the dispute out of court." 31

The principles of equivalence and effectiveness or the principle of effective judicial protection do not "preclude national legislation which imposes, in respect of such disputes, prior implementation of an out-of-court settlement procedure, provided that that procedure does not result in a decision which is binding on the parties, that it does not cause a substantial delay for the purposes of bringing legal proceedings, that it suspends the period for the time-barring of claims and that it does not give rise to costs - or gives rise to very low costs - for the parties, and only if electronic means is not the only means by which the settlement procedure may be accessed and interim measures are possible in exceptional cases where the urgency of the situation so requires." 32 This case law has then been interpreted by legal scholars as a wholehearted endorsement of "schemes for mandatorily re-routing litigants away from the courts and into ADR schemes" (de Roo and Jagtenberg, 2012: 27).

\section{Celerity of proceedings as an argument}

Long, onerous, costly and also sometimes physically burdensome court proceedings in civil matters are not something parties wish for. Effects of specific Slovenian development felt by applicants before courts of first instance has led to a rather negative approach of judges to litigants who do not want to conclude a court settlement or mediate.

In the normal course of events the finding made by US legal scholars that "the large volume of cases filed, the soaring costs, and the long delays made the courts an unattractive arena for resolving differences. The profession was forced to look seriously for other means of resolution. One answer was mediation, a system that was more efficient, less costly, less time-consuming and friendlier". The same has been discussed and appliesto the Slovenian experience (Calkins, 2011: 4).

However, sometimes the defendant will want to have a full litigation due to several factors, such as the foreseen loss of interest by the claimant in the course of proceedings, the claimant's financial inability to litigate or even simply that the delay in the case is beneficial for the defendant (e.g. in intellectual property law, where the compelling 


\section{LEXONOMICA \\ J. Sladič: The Argument for Choosing State's Judicial System or a "Private" Outsourced Resolution of Disputes: a Practising Attorney's Point of View}

judgement ordering the cessation of infringement will be adopted only after several years of litigation). ${ }^{33}$ In other words, it might happen that the defendant will seek the most burdensome way to settle a dispute in order to discourage the claimant's effort to get a speedy and efficient resolution of a dispute. The outsourced solution of disputes might also be burdensome for claimants. Slovenian jurisprudence concerns, for example arbitration clauses in commercial litigation with monetary value lower than 3.000,00 Euro. Due to the peculiar system of legal fees of attorneys, the fees are identical in arbitration/mediation and litigation before a trial court. In other words, an applicant will have to pay an attorney the same amount in order to litigate a small value claim before a court of first instance as in the case of an arbitration or mediation. Instead of paying a small stamp duty in small value cases the claimant will have to pay a full fee for an arbitrator. In such cases even arbitration might act as a deterrent.

\section{Confidentiality and the facility to organise the proceedings according to parties' wishes}

A rather unfortunate event in civil litigation before the court of first instance in Ljubljana in late 2014 has lead a trial judge to menace the parties: ${ }^{34}$ "if you do not conclude a court settlement, I will fix ten hearings that will cause you many costs." This is the direct consequence of socialist tradition. It is known that the "judicial job in socialism was regularly not an uncomfortable job, especially to those who could adapt to the requirements." Rather, "the need for a speedy resolution of a case was relative to the importance of the case. Most of the cases were not too important, so the pressure for a timely decision was not particularly strong" (Uzelac, 2010: 387).

An outsourced dispute resolution clearly would not allow such an arrogant attitude to parties. The main advantage of any outsourced resolution of disputes in Slovenia is the complete flexibility left to parties. Indeed, even institutional mediation, according to the Slovenian Act on Mediation in Civil and Commercial Matters, parties can reach an agreement on how to conduct a mediation. This can also be reached by referring to any other existing rule (e.g. Ljubljana arbitration rules of the arbitration centre at the chamber of commerce and industry of Slovenia). If parties do not have an agreement on the course of mediation, the mediator shall conduct the proceedings as he/she deems appropriate. ${ }^{35}$

\section{Bodies of public law and State owned enterprises and their peculiar approach to dispute resolution}

In Slovenian practice cases of faked acceptance of mediation and arbitration or any other outsourced dispute resolution by the party who is not prepared to accept a negotiated and outsourced solution are not that rare. If there were to be a dispute with the public authorities, State or a State owned enterprise or legal person that can be adjudicated by civil courts applying the rules of civil procedure (in Slovenia any dispute concerning patrimonial issues, including the damages caused by State's performance of coercive powers) then any possibility of outsourced dispute resolution might be rather negative. ${ }^{36}$ 
The logic followed by the decision makers in such bodies is: I will be held liable for any negotiated solution. On the other hand, there is a possibility that a State's court might rule against us. Such an eventuality, however, is a decision handed down by an independent court and we cannot go against the enforceable and final decision handed down by courts. It is in a manner of speaking a vis maior, we cannot influence and cannot be held liable for such a decision. Therefore, any civil or commercial case where a claimant requests a higher pecuniary consideration from public bodies or enterprises will never be settled by an outsourced solution of disputes. Such is still a very bureaucratic apparatchik type of mentality of the Slovenian public sector.

Special rules are actually in force for civil disputes with the State. Under Art. 14 of the Slovenian Act on the State's Attorneys a claimant shall first attempt a friendly settlement with the State in case of an intended civil lawsuit against the State. ${ }^{37}$ However, such an attempt is not a condition of admissibility of civil proceedings. ${ }^{38}$ Nevertheless, according to Art. 21 of the Slovenian Act on Alternative Resolution of Judicial Disputes the State's attorneys shall give their agreement to mediation in cases where such an agreement shall be appropriate under the circumstances of the case. If the State's attorney considers that a resolution of a dispute with mediation is not appropriate, he/she shall require by virtue of a reasoned request a decision by the government of the Republic of Slovenia. In other words, the council of ministers presided by the prime minister will have to issue a decision if mediation in a single commercial, civil or labour lawsuit is appropriate. Of course, this legislative provision is at odds with the basic aim of mediation, namely a speedy resolution of disputes. Indeed, under Art. 15(1) of the Slovenian Act on Alternative Resolution of Judicial Disputes an alternative (i.e. outsourced) resolution of a dispute shall not last longer than three months. It is rather a rare eventuality that the council of ministers presided by the prime minister will find time to give a favourable opinion or any for that matter in less than three months.

In practice, if a civil case presents a certain amount of novelty and uncertainty, there will be no outsourced dispute resolution with the State owned enterprises or authorities.

\section{Conclusion}

Much has been written on the advantage of outsourced dispute resolution. Terms such as arbitration, mediation, conciliation and ADR are nowadays standard terms in any classroom textbook on civil procedure. Legal writers enumerated and assessed in depth the advantages and disadvantages of any type of outsourced dispute resolution. However, a number of legal writers still fail to enumerate the exact course of events and all tradeoffs that a party will have to do when deciding to resolve the dispute using an outsourced dispute resolution. Clearly, the costs, the celerity and the flexibility are important issues. However, the decision is not influenced solely by legal arguments. This paper mentioned some typical Slovenian issues in assessment of the choice of dispute resolution. If parties want to continue to remain in good terms after the dispute, then an outsourced dispute 


\section{LEXONOMICA J. Sladič: The Argument for Choosing State's Judicial System or a "Private" Outsourced Resolution of Disputes: a Practising Attorney's Point of View}

resolution is strongly suggested. Judicial rulings are to binary, either a party wins or a party loses.

\section{Notes}

${ }^{1}$ Art. 9 Slovenian Code of Obligations, OJ of the Republic of Slovenia, Nr. 83/2001 et seq.

${ }^{2}$ Annuaire de la Convention Europeenne des droits de l'homme 1986, p. 225.

${ }^{3}$ Zakon o alternativnem reševanju sodnih sporov (ZARSS), OJ of the Republic of Slovenia, Nr. 97/09.

${ }^{4}$ Court of Appeal in Labour and Social Matters of the Republic of Slovenia, order in case Pdp 935/2005, ECLI:SI:VDSS:2005:VDS.PDP.935.2005

5 See e.g. Recommandation adopted by the International Labour Organisation like Recommendation concerning Voluntary Conciliation and Arbitration, 1951 (No. 92), Recommendation concerning the Examination of Grievances within the Undertaking with a View to Their Settlement 1967 (No. 130).

${ }^{6}$ Alan Uzelac (Uzelac, 2010: 383, 388 and 389) explains that "most of the socialist judiciary has developed, over time, numerous methods aimed at evading responsibility for decision-making. Unlike the heroic figure of the common law judge, who strives to contribute to legal history through prudent, brave and well-reasoned judgments, socialist judges, in the fear of eventual retribution, always desired to remain as anonymous as possible. In this respect, they were akin to their counterparts from civil law traditions. This went even further, however: a safer alternative to an anonymous decision was no decision at all, and, hence, no settlement." (at 383) [...] "Under the new circumstances, courts became removed from the shade of the relatively unimportant decisionmaking in petty cases. With the privatization of economic resources and the pluralization of political life, a growing number of important social issues began to arrive at the courts. The result was massive inefficiency: court backlogs and judicial delays started to accumulate throughout the countries of the former Socialist bloc. The length of the proceedings was among the most visible symptoms of residual similarity to the legal systems of the third (i.e., socialist) legal tradition." (at $388)[\ldots]$ "it became evident that a large majority of the former socialist countries had a serious problem with one right in particular: the right to a trial within a reasonable time." (at 389).

${ }^{7}$ Court of Appeal of Ljubljana, order in case I Cp 321/2012, ECLI:SI:VSLJ:2012:I.CP.321.2012.

${ }^{8}$ Art. 25 Slovenian Act on Arbitration (OJ of the Republic of Slovenia, Nr. 45/08).

${ }^{9}$ Zakon o mediaciji v civilnih in gospodarskih zadevah (ZMCGZ, OJ of the Republic of Slovenia, Nr. 56/08).

${ }^{10}$ Zakon o pravdnem postopku (ZPP, OJ of the Republic of Slovenia, Nr. 26/1999 et seq).

${ }^{11}$ Ugotovitvena tožba (Feststellungsklage), see Art. 181 of the Slovenian Code of Civil Procedure.

12 Oblikovalna tožba (Gestaltungsklage).

${ }^{13}$ Dajatvena tožba (Leistungsklage).

${ }^{14}$ In Slovenian law the effects of a judicial compromise (res transacta) are identical to res iudicata effects of judgements issued by courts.

${ }^{15}$ Art. 305c(1) of the Slovenian Code of Civil Procedure (repealed).

16 Court of Appeal of Ljubljana, judgement in case I Cpg 890/2011, SI:ECLI:SI:VSLJ:2012:I.CPG.890.2011.

${ }^{17}$ Art. 305c(2) of the Slovenian Code of Civil Procedure (repealed).

${ }^{18}$ Court of Appeal in Labour and Social Matters of the Republic of Slovenia, order in case Pdp 1828/2003. SI:ECLI:SI:VDSS:2003:VDS.PDP.1828.2003.

19 Supreme Court of the Republic of Slovenia, judgement in case III Ips 65/2012, ECLI:SI:VSRS:2013:III.IPS.65.2012 
20 Supreme Court of the Republic of Slovenia, judgement in case II Ips 215/2013, ECLI:SI:VSRS:2015:II.IPS.215.2013

${ }^{21}$ Supreme Court of Slovenia, order in case II Ips 711/95, ECLI:SI:VSRS:1995:II.IPS.711.95.

22 Supreme Court of the Republic of Slovenia, judgement in case I Up 738/2005, ECLI:SI:VSRS:2006:I.UP.738.2005.

${ }^{23}$ Supreme Court of Slovenia, order in case II Ips 281/97, ECLI:SI:VSRS:1998:II.IPS.281.97.

${ }^{24}$ Art. 41 of Slovenian Arbitration Act.

${ }^{25}$ Translation provided by the Ministry of Justice of the Republic of Slovenia.

${ }^{26}$ Art. 2(3) and Art. 2(4) of the Slovenian Act on Mediation in Civil and Commercial Matters.

${ }^{27}$ See e.g. Art. 3(3) Slovenian Code of Civil Procedure.

${ }^{28}$ Art. 47 Slovenian Act on Notaries, Official Journal of the Republic of Slovenia Nr. 48/94 et seq.

${ }^{29}$ Zakon o mediaciji v civilnih in gospodarskih zadevah (ZMCGZ, OJ of the Republic of Slovenia Nr. 56/08).

${ }^{30}$ ECHR, Regent Company v Ukraine, § 54, ECLI:CE:ECHR:2007:0410DEC000077303.

${ }^{31}$ Joined cases C-317/08, C-318/08, C-319/08 and C-320/08, Alassini, ECLI:EU:C:2010:146, par. 67.

32 Id.

33 See e.g. Court of Appeal of Ljubljana, judgement and order in case V Cpg 251/2015, ECLI:SI:VSLJ:2015:V.CPG.251.2015 where it appears that a case on cessation of illicit use of a trademark pended between 2011 and 2015 before a final resolution.

${ }^{34}$ Nomina sunt odiosa.

${ }^{35}$ Art. 8(1) and Art. 8(2) of the Slovenian Act on Mediation in Civil and Commercial Matters

${ }^{36}$ See e.g. Art. 26 Slovenian Constitution.

${ }^{37}$ The Slovenian Act on State Attorneys (OJ of the Republic of Slovenia, Consolidated version, Nr. 94/07)

38 Court of Appeal of Ljubljana, order in case II Cp 6109/2005, ECLI:SI:VSLJ:2005:II.CP.6109.2005.

\section{References}

Betetto, N. in Galič, A. (2009) "Poravnalni narok in sodna poravnava", p. 17-49, in Ude, L. et al. (eds.), "Pravdni postopek, Zakon s komentarjem" (Ljubljana: Uradni list).

Braun, J. (2014) Lehrbuch des Zivilprozeßrechts (Tübingen: J. C. B. Mohr).

Calkins, R., M. (2011) "Mediation: A Revolutionary Process that is Replacing the American Judicial System", Rutgers Conflict Resolution Law Journal, 13(1), p. 1-59.

de Roo, A., and Jagtebnerg, R. (2012) "The Relevance of Truth, The Case of Mediation versus Litigation", p. 27-46, in: van Rhee, C. H. \& Uzelac, A. (eds.), "Truth and Efficiency in Civil Litigation" (Cambridge/Antwerp/Portland: Intersentia).

Đuričin, B. (2013) "Pregovaranje kao metoda alternativnog rješavanja sporova", p. 605-613, in: Uzelac, A. in Garašić, J. in Maganić, A. (eds), "Djelotvorna pravna zaštita u pravičnom postupku, Liber amicorum Mihajlo Dika” (Zagreb: Pravni fakultet Sveučilišta u Zagrebu).

Eiseman, N. M., Bulman, J., in Dunn, Th. R. (2013) "A Tale of Two Lawyers: How Arbitrators and Advocates Can Avoid the Dangerous Convergence of Arbitration and Litigation", Cardozo journal of conflict resolution, 14, p. 683-725.

Jovin - Hrastnik, B. (2009) "Med obveznim in neobveznim alternativnim reševanjem sporov", Podjetje in delo, 35(6-7), p. 1123-1130.

Juhart, J. (1962) Civilno izvršilno pravo - oris (Ljubljana: Univerzitetna založba).

Jung, F. (2014) "Die Sportschiedsgerichtsbarkeit im Lichte des Art. 6 EMRK", Zeitschrift für europarechtliche Studien, 17(2), p. 173-209.

Knežević, G. (2012) Marginalije o pojmovima privatne pravde i ADR-a s aspekta arbitraže i medijacije, Zagreb: Zbornik Pravnog fakulteta u Zagrebu, 62(1-2), p. 417-436. 


\section{LEXONOMICA \\ J. Sladič: The Argument for Choosing State's Judicial System or a "Private" Outsourced Resolution of Disputes: a Practising Attorney's Point of View}

Langbein, J. H. (2012) “The Demise of Trial in American Civil Procedure: How it Happened, Is It Convergence with European Civil Procedure?" p. 119-194, in: van Rhee, C. H. in Uzelac, A. (eds.), "Truth and Efficiency in Civil Litigation" (Cambridge/Antwerp/Portland: Intersentia).

Miranda, A. (2014) "The origins of mediation and the A.D.R. Tools", p. 9-26, Miranda, A. (ed.), "Mediation in Europe at the cross-road of different legal cultures" (Ariccia: Aracne editrice).

Sajovic, R. (1939) Civilni pravdni postopek s kratkimi pojasnili (Ljubljana: Univerzitetna tiskarna).

Schütz, J. G. (2015) Europäische Richtlinie über bestimmte Aspekte der Mediation in Zivil- und Handelssachen, Aktuelle Juristische Praxis/Pratique actuelle juridique, 1, p. 106122.

Sikirić, H. (2013) "Pravo mjerodavno za objektivnu arbitrabilnost", p. 493 - 519, in: Uzelac, A \& Garašić, J. \& Maganić, A. (eds), "Djelotvorna pravna zaštita u pravičnom postupku, Liber amicorum Mihajlo Dika”, Zagreb: Pravni fakultet Sveučilišta u Zagrebu, 2013.

Spillane, J. P., Oyedele, L. O., Hande, E., von Meding, J., Konanahalli, A., Jaiyeoba, B. E. in Tijani, I. K. (2011), "Mediation within Irish construction industry: Identifying success factors for appropriate competencies and processes", Journal of Law and Conflict Resolution, 8(3), p. 142-150, available online at http://www.academicjournals.org/JLCR.

Škundrić, P. (2012) Mediacija kot oblika alternativnega reševanja individualnih delovnih sporov primerjalno pravni pregled z Anglijo, LL.M. paper (Maribor: Pravna fakulteta).

Stürner, R. (2014) "Liberalismus und Zivilprozess", Österreichische Jurristen-Zeitung, 64(14-15), p. 629-639.

Uzelac, A. (2010) "Survival of the Third Legal Tradition", Supreme Court Law Review, 49, p. 377396.

Uzelac, A., Aras, S., Maršić, M., Mitrović, M., Kauzlarić, Ž., Stojčević, P. (2010), "Aktualni trendovi mirnog rješavanja sporova u Hrvatskoj : dosezi i ograničenja”, Zagreb: Zbornik Pravnog fakulteta u Zagrebu, 60(3), p. 1265-1308. 
LEXONOMICA 